\title{
Optimization and Validation of Molecular Assays for Invasive Tunicate Monitoring in Environmental Water Samples
}

\author{
Sarah Elizabeth Stewart-Clark (Corresponding author) \\ Dept. of Plant and Animal Science, Dalhousie Faculty of Agriculture \\ 58 River Road, Truro, NS B2N 5E3, Canada
}

Tel: 1-902-893-8072Ｅ-mail: sstewartclark@nsac.ca

Jeffrey Davidson

Dept. of Health Management, Atlantic Veterinary College, UPEI

550 University Ave, Charlottetown, PEI C1A 4P3, Canada

Tel: 1-902-566-0666 E-mail: davidson@upei.ca

Spencer J. Greenwood

Dept. of Biomedical Sciences, Atlantic Veterinary College, UPEI

550 University Ave, Charlottetown, PEI C1A 4P3, Canada

Tel: 1-902-566-6002 E-mail: greenwood@upei.ca

Received: October 1, 2012 Accepted: December 12, 2012 Published: January 1, 2013

doi:10.5296/ast.v1i1.2979 URL: http://dx.doi.org/10.5296/ast.v1i1.2979

\begin{abstract}
There are currently four invasive tunicate species which are causing significant challenges to the aquaculture industry in Atlantic Canada: Ciona intestinalis, Styela clava, Botryllus schlosseri and Botrylloides violaceus. Molecular PCR based assays have been developed in previous studies as high throughput screening tools for invasive tunicate monitoring in Atlantic Canada. In this study, field validation experiments were conducted to ensure that assay efficacy and sensitivity would not be impacted by components in the environment which are known PCR inhibitors. Two sets of protocols were optimized for screening
\end{abstract}


sediment rich mussel processing plant effluent, and sediment light bay water surrounding mussel leases, as DNA extraction method and DNA sample dilution were both shown to impact assay efficacy and sensitivity in different water sample conditions. In addition, the efficacy, sensitivity and specificity of all four assays were compared to the current industry standard method of microscope analysis of water samples for invasive tunicate egg and larvae detection at the bay level. All four assays exhibited high sensitivity 1-5 eggs/larvae in all water conditions and had comparable sensitivity and efficacy with the current industry standard.

Keywords: Tunicates, Molecular assays, COI, 18S rDNA, Invasive species, Monitoring 


\section{Introduction}

Invasive tunicates are currently causing significant fouling problems to the shellfish aquaculture industry in Prince Edward Island, Canada (Thompson \& McNair, 2004; Ramsay et al., 2008). To help manage and aid in early detection of these tunicates, species specific PCR based molecular assays were developed and laboratory tested to detect egg and larval stages of four invasive tunicates in water samples: Ciona intestinalis (Linnaeus, 1758), Styela clava (Herdman, 1881), Botrylloides violaceus (Oka, 1927) and Botryllus schlosseri (Pallas, 1766) (Stewart-Clark et al., 2009). While laboratory validation occurs under controlled conditions, components of the field sample such as humic acids, phenolic compounds, heavy metals, organic and inorganic chemicals, algae and non-target DNA can inhibit molecular assays and impact sensitivity and/or efficacy (Tebbe \& Vahjen, 1993; Johnson et al., 1995; Wilson, 1997; Toze, 1999; Cunningham, 2002). Field sampling protocols and sample handling can also limit assay efficacy (Jacobson, 1996; Hoorfar et al., 2004). For these reasons it is critical for molecular assays and field sampling methods to be validated before assays can be implemented into monitoring and surveillance programs (Cunningham, 2002; Jacobson, 1996).

According to the Mussel Monitoring Program, operated by the PEI Department of Fisheries, Aquaculture and Rural Development (2009), and research by the Department of Fisheries and Oceans Canada (Bourque, 2006), two types of water sources in Atlantic Canada have been highlighted as important areas for monitoring programs for tunicate eggs and larvae. As a result, these two different types of field water (bay water surrounding mussel leases and mussel processing plant effluent water) were used in the field validation of the species specific assays in this study. Many studies have shown that PCR inhibitors can reduce sensitivity and/or efficacy in molecular assays that involve surface and effluent water samples or other environmental samples that contain sediment (Tebbe \& Vahjen, 1993; Toze, 1999; Xiao et al., 2001; Alexandrino et al., 2004; Kourenti \& Karanis, 2006; Whitehorse \& Hottel, 2007). Different methods have been successful at increasing assay sensitivity in the presence of inhibitory compounds, such as the use of specialized DNA extraction protocols or kits that remove PCR inhibitors (Alexandrino et al., 2004; Kemp et al., 2006; Behets et al., 2007; Whitehouse \& Hottel, 2007), diluting DNA samples to dilute inhibitory compounds (Verkooyen et al., 1996; Altshuler, 2006; Kemp et al., 2006) and altering collection methods to decrease the sample concentration and simultaneously PCR inhibitor concentration (Hoorfar et al., 2004).

In this study, two different methods of water sampling were evaluated for use with these assays: direct grab sampling and concentrated-sieved sampling. Sample type can significantly impact PCR assays since different samples contain different inhibitory compounds and sampling procedures can impact the quantity of target material collected if present (Hoorfar et al., 2004). In addition, two different DNA extraction kits were used to extract DNA from water samples: Qiagen DNeasy Blood and Tissue Kit and Norgen Soil DNA Isolation Kit. Using DNA extraction methods (such as the Norgen kit) with targeted steps to reduce levels of inhibitory compounds in DNA samples have been shown to increase PCR sensitivity in other studies (Alexandrino et al., 2004; Behets et al., 2007; Whitehorse \& Hottel, 2007). 
Thirdly, diluting DNA samples by two-fold and ten-fold amounts before PCR was also evaluated as a method to decrease the impact of inhibitory compounds on assay results as has been shown in other studies (Verkooyen et al., 1996; Altshuler, 2006; Kemp et al., 2006). Through the evaluation of the impact of these three components of the assay protocol, it is hoped that a standardized assay protocol can be developed and optimized for samples from both field conditions. Once protocols have been standardized, field validation studies for molecular assays which test sensitivity and repeatability, involve either samples spiked with known quantities of target material (Patil et al., 2005; Boeger et al., 2007; Darling \& Tepolt, 2008), or surveys of environmental samples with unknown quantities of the target species (Jacobson, 1996; Boeger et al., 2007). An imperative step in any new assay validation is also a comparison against the current industry standard (Jacobson, 1996; Hoorfar et al., 2004; Boeger et al., 2007), which for invasive tunicate monitoring on PEI is microscopic analysis of water samples.

There were three main objectives to this study: 1 . To optimize and create standardized assay protocols for samples collected from field conditions, 2 . To validate the standardized assay protocol with sensitivity and repeatability tests using spiked samples in two different types of field water samples, and 3. To directly compare assay results from the primers developed in this study with results of the industry standard microscope analysis of bay water samples in PEI (Gill et al., 2007).

\section{Materials and Methods}

\subsection{Water Samples}

Water samples were collected from two different water types (mussel processing effluent water and bay water) using two different sampling methods (direct grab and sieve concentrated). Mussel processing effluent water was collected from the effluent outflow pipe of a mussel processing plant in New London, Prince Edward Island, Canada (N46.48685 W63.49969). Water was collected on July 14, 2008 using both the direct grab and sieve concentrated methods. A 1 litre direct grab sample was collected from the effluent water pipe just before entry into New London Bay and aliquoted into $50 \mathrm{ml}$ tubes before freezing at $-80^{\circ} \mathrm{C}$ until further use. The sieve-concentrated samples were collected by passing 30 litres of effluent water flow through a $75 \mu \mathrm{m}$ sieve. The material collected in the sieve was flushed into an Erlenmeyer flask using 1 litre of filtered artificial seawater (Derived from DFO protocol; Daniel Bourque personal communication). The water was then aliquoted into $50 \mathrm{ml}$ tubes and frozen at $-80^{\circ} \mathrm{C}$ until further use. Bay water surrounding a mussel lease was collected in July 2009 from St. Mary's Bay, Prince Edward Island, Canada (N46.12537 W62.49876). A 1 litre direct grab sample was collected from the bay surface water, aliquoted into $50 \mathrm{ml}$ tubes and frozen at $-80^{\circ} \mathrm{C}$ until further use. Sieve-concentrated samples were collected by continuously lowering and raising a bilge pump through the water column over a 3 minute period pumping 150 litres of water through a $75 \mu \mathrm{m}$ sieve. Contents collected in the sieve were washed into containers using $500 \mathrm{ml}$ of water (Protocol derived from Gill et al. 2007). Water samples were aliquoted in $50 \mathrm{ml}$ tubes and frozen at $-80^{\circ} \mathrm{C}$ until further use. 


\subsection{Optimization of Assay Protocol}

\subsubsection{DNA Extraction Protocol Evaluation}

For each of the four water sample types (mussel processing effluent direct grab, mussel processing effluent sieve concentrated, bay water direct grab, bay water sieve concentrated) two methods of DNA extractions were performed on quantities of 1-100 Ciona eggs or larvae to evaluate the efficacy of each DNA extraction kit in removing PCR inhibitors from the water samples. The two DNA extraction kits evaluated in this study were the Qiagen DNeasy Blood and Tissue Minikit (Qiagen Inc, Canada) and the Norgen Soil DNA Isolation Kit (Norgen Biotek Corp, Canada). For the Qiagen extractions, an extra step was added to the manufacturer's protocol to remove sediment from the DNA sample. Following the addition of Buffer AL, tubes were vortexed and then centrifuged at $14000 \mathrm{~g}$ for 1 minute. The supernatant was transferred to a new $1.5 \mathrm{ml}$ tube and $200 \mu \mathrm{l}$ of ethanol was added. The remainder of the protocol followed the manufacturer's directions. The Norgen Kit DNA extractions were all done according to the manufacturer's protocol.

\subsubsection{Sample Dilution PCR Experiment}

PCR was performed in $25 \mu 1$ final volume containing $12.5 \mu \mathrm{l}$ AmpliTaq Gold PCR Master Mix (Applied Biosystems manufactured by Roche, Branchburg, New Jersey), 10 pmol appropriate species forward primer, $10 \mathrm{pmol}$ appropriate species reverse primer, 1-60 ng appropriate DNA and $9.5 \mu \mathrm{l}$ sterile nuclease free $\mathrm{ddH}_{2} 0$. Preliminary PCR tests included DNA samples diluted two-fold and ten-fold to investigate the impact of PCR inhibitors on amplification. Samples were denatured for 3 minutes at $92^{\circ} \mathrm{C}$, amplified over 35 cycles consisting of 1 minute at $94{ }^{\circ} \mathrm{C}$ for denaturation, 1 minute at annealing temperatures specific for each primer set: $50^{\circ} \mathrm{C}(\mathrm{C}$. intestinalis $), 53{ }^{\circ} \mathrm{C}(\mathrm{B}$. schlosseri $), 58{ }^{\circ} \mathrm{C}(\mathrm{S}$. clava $)$, or $62{ }^{\circ} \mathrm{C}(\mathrm{B}$. violaceus) for primer annealing, and 3 minutes at $72{ }^{\circ} \mathrm{C}$ for elongation. Following the last cycle, polymerization was extended for 5 minutes at $72^{\circ} \mathrm{C}$ to complete elongation. PCR amplicons were separated in $1 \%$ agarose gels containing $0.5 \mu 1 / \mathrm{ml}$ SYBR Green and visualized using ultraviolet light. $20 \mu \mathrm{l}$ of PCR sample and $3 \mu 1$ loading dye were added to each well. Images were captured using VersaDoc Imager (Bio-Rad).

\subsection{Sensitivity and Repeatability Study with Spiked Water Samples}

Once the protocol optimization was completed, sensitivity and repeatability trials were conducted using the optimized protocol with water samples spiked with known species and quantity of target material. For sensitivity studies involving solitary tunicates, both unfertilized eggs and free swimming larval stages were used. Unfertilized eggs were manually collected from Ciona intestinalis and Styela clava specimens in the lab. These eggs were then placed in microcentrifuge tubes filled with bay or mussel processing effluent water in quantities of $1,5,10,20,50$, and 100 . Each quantity was replicated 5 times. The samples were then centrifuged at $14000 \mathrm{~g}$ for 2 minutes, water was removed and DNA was extracted from the pelleted material. Free swimming larvae were produced in the lab by removing egg and sperm samples from Ciona intestinalis and Styela clava. These gametes were then placed in Petri dishes with filtered sea water and left for 15-17 hours to develop into free swimming 
larvae. Free swimming larvae were individually collected by pipette using a dissecting microscope and placed in microcentrifuge tubes filled with bay or mussel processing plant effluent water in $1,5,10,20,50$, and 100 quantities. The samples were then centrifuged at 14 $000 \mathrm{~g}$ for 2 minutes, water was removed and DNA was extracted from pelleted material. Since the colonial tunicates used in this study spread most often via fragments of adult colonies, individual zooids and small fragments of colonies were used for sensitivity testing for Botryllus schlosseri and Botrylloides violaceus. Individual zooids and colonies were placed in microcentrifuge tubes filled with water samples. Each quantity (zooid and colony) was replicated 5 times for each species. The microcentrifuge tubes were then centrifuged at $14000 \mathrm{~g}$ for 2 minutes, water was pipetted off and DNA extractions were performed. DNA was extracted from bay water using the Qiagen DNeasy Blood and Tissue kit (Qiagen Inc, Canada) while DNA was extracted from mussel processing effluent water using the Norgen Soil DNA Isolation Kit (Norgen Biotek Corp, Canada).

\subsection{Comparison with Industry Standard}

Water samples were collected from seven areas on PEI from August 10-12 2009 (Table 1) as part of the Mussel Monitoring Program by the PEI Department of Fisheries, Aquaculture and Rural Development. Water samples were collected by continuously lowering and raising a bilge pump through the water column over a 3 minute period pumping 150 litres of water through a $64 \mu \mathrm{m}$ sieve. The collected materials were then washed from the sieve into tubes using approximately $25 \mathrm{ml}$ of water. Water samples were brought back to the provincial laboratory where they were spread on a $64 \mu \mathrm{m}$ sieve and then washed into a $100 \mathrm{ml}$ beaker with $10 \mathrm{ml}$ tap water. $10 \mathrm{ml}$ of water was then removed from the beaker and examined through a microscope with a counting wheel for the presence of tunicate eggs and larvae. Once the samples were surveyed, water samples were returned to collection tubes and maintained at $-4^{\circ} \mathrm{C}$ for 2 days. Samples were then transferred to the molecular lab where they were stored at $-80^{\circ} \mathrm{C}$ until DNA extractions were performed. Microscopic analysis was conducted by a biologist from the PEI Department of Fisheries, Aquaculture and Rural Development while molecular analysis occurred at the Atlantic Veterinary College. Researchers were blinded to the results of the other method.

For molecular analysis, water samples were thawed and centrifuged at $5250 \mathrm{~g}$ for 15 minutes to pellet material. Pelleted material contained so much sediment $(>100 \mu 1)$, that Norgen Soil DNA Isolation Kits were used to extract DNA from each sample instead of Qiagen DNeasy Blood and Tissue kits. DNA extractions followed manufacturer's protocol (Norgen Biotek, Guelph Canada). PCR was performed in $25 \mu 1$ final volume containing $12.5 \mu 1$ AmpliTaq Gold PCR Master Mix (Applied Biosystems manufactured by Roche, Branchburg, New Jersey), 10 pmol appropriate species forward primer, 10 pmol appropriate species reverse primer, 1-60 ng appropriate DNA and 9.5 $\mu$ s sterile nuclease free $\mathrm{ddH}_{2} 0$. All DNA samples were diluted ten-fold with nuclease free $\mathrm{ddH}_{2} \mathrm{O}$ prior to PCR. Samples were denatured for 3 minutes at $92^{\circ} \mathrm{C}$, amplified over 35 cycles consisting of 1 minute at $94^{\circ} \mathrm{C}$ for denaturation, 1 minute at annealing temperatures specific for each primer set, $50^{\circ} \mathrm{C}(\mathrm{C}$. intestinalis $), 53{ }^{\circ} \mathrm{C}(\mathrm{B}$. schlosseri), $58{ }^{\circ} \mathrm{C}$ (S. clava), or $62{ }^{\circ} \mathrm{C}$ (B. violaceus), and 3 minutes at $72{ }^{\circ} \mathrm{C}$ for elongation. Following the last cycle, polymerization was extended for 5 minutes at $72^{\circ} \mathrm{C}$ to complete 
elongation. PCR amplicons were separated on $1 \%$ agarose gels containing $0.1 \mu 1 / \mathrm{ml}$ SYBR Safe and visualized using ultraviolet light. $20 \mu \mathrm{l}$ PCR product and $3 \mu 1$ loading dye was added to each gel lane. Images were captured using a VersaDoc Imager (Bio-Rad).

Table 1. Water samples collected for comparison of molecular assays against current industry standard (microscope analysis)

\begin{tabular}{lll}
\hline Date of Water Collections & Site of Water Collections (PEI, Canada) & GPS Location \\
\hline August 10, 2009 & Boughton River & N46.26522; W62.45951 \\
August 10, 2009 & Cardigan River & N46.167; W62.467 \\
August 11, 2009 & Montague River & N46.176389; W62.570833 \\
August 11, 2009 & St. Mary's Bay & N46.12749; W62.51536 \\
August 11, 2009 & Murray River & N46.02856; W62.54969 \\
August 12, 2009 & Darnley Basin & N46.550; W63.667 \\
August 12, 2009 & Marchwater in Malpeque Bay & N46.517; W63.717 \\
August 12, 2009 & Marchwater & N46.517; W63.717 \\
August 12, 2009 & Marchwater & N46.517; W63.717 \\
\hline
\end{tabular}

\section{Results}

\subsection{Optimization of Assay Protocols}

\subsubsection{Bay Water}

All DNA samples extracted from various quantities of $C$. intestinalis larvae in direct grab bay water using the Qiagen DNeasy Blood and Tissue extraction kits were amplified during PCR. Amplicons were generated in all dilution categories including full strength, two-fold and ten-fold dilutions (Figure 1A). No DNA samples extracted from various quantities of $C$. intestinalis larvae in direct grab bay water using the Norgen Soil DNA Isolation kit were successfully amplified using PCR. This trend held true in all dilution categories (Figure 1B). In sieve-concentrated bay water samples, DNA extracted from all quantities of Ciona eggs using the Norgen Soil DNA Isolation kit were amplified in the ten-fold dilution series. None of the two-fold dilution samples were amplified while the 10-100 larval sample quantities were amplified in the undiluted samples (Figure 2A). All DNA samples extracted using the Qiagen DNeasy kit from 1-100 Ciona eggs in sieve-concentrated bay water samples were amplified during PCR in all dilution categories (Figure 2B). 


\section{Macrothink}

\subsubsection{Mussel Processing Plant Effluent Water}

The only amplicons produced during PCR with mussel processing water samples were extracted using the Norgen Soil DNA Isolation kit. No amplicons were produced in the undiluted or $2 \mathrm{X}$ concentrated direct grab Norgen extracted DNA samples; however, DNA was successfully amplified in two-fold and ten-fold diluted samples (Figure 3A). In sieve-concentrated mussel processing water samples, amplicons were produced in the 50 and 100 quantity undiluted samples; however, amplicons from as little as 5 eggs were amplified in the two-fold and ten-fold diluted samples (Figure 4A). No DNA samples extracted from $C$. intestinalis eggs in mussel processing plant effluent using the Qiagen DNeasy kits were amplified during PCR. This trend was seen in both water sample types (direct and sieve-concentrated) and in all DNA sample dilutions used in PCR (1X, 2X, two-fold and ten-fold dilutions) (Figures 3B and4B).
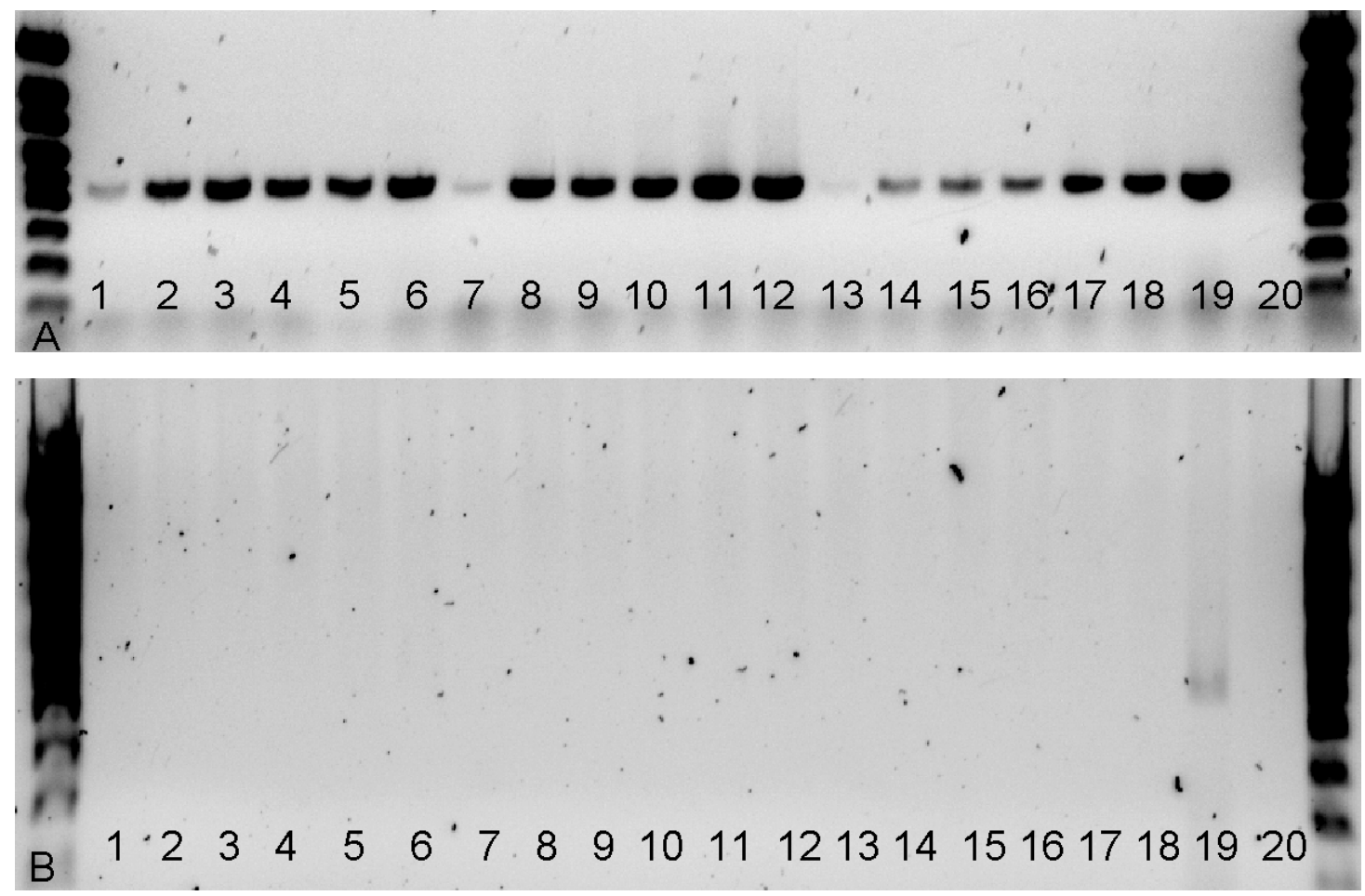

Figure 1 A. Agarose gel of PCR amplicons from DNA samples extracted using Qiagen DNeasy DNA extraction kit from direct grab bay water samples spiked with known quantities of Ciona larvae. B. Agarose gel of PCR amplicons from DNA samples extracted using Norgen Soil DNA Isolation kit from direct grab bay water samples spiked with $C$. intestinalis larvae. Ln1=1 larva (undiluted). Ln2=5 larvae (undiluted). Ln3=10 larvae (undiluted). Ln4=20 larvae (undiluted). Ln5=50 larvae (undiluted). Ln6=100 larvae (undiluted). Ln7=1 larva (2-fold dilution). Ln8=5 larvae (2-fold dilution). Ln9=10 larvae (2-fold dilution). Ln10=20 larvae (2-fold dilution). Ln11=50 larvae (2-fold dilution). Ln12=100 larvae (2-fold dilution). Ln13=1 larva (10-fold dilution). Ln14=5 larvae (10-fold dilution). Ln15=10 larvae (10-fold dilution). Ln16=20 larvae (10-fold dilution). Ln17=50 larvae (10-fold dilution). Ln18=100 larvae (10-fold dilution). Ln19= Positive control. Ln20= Negative control. 

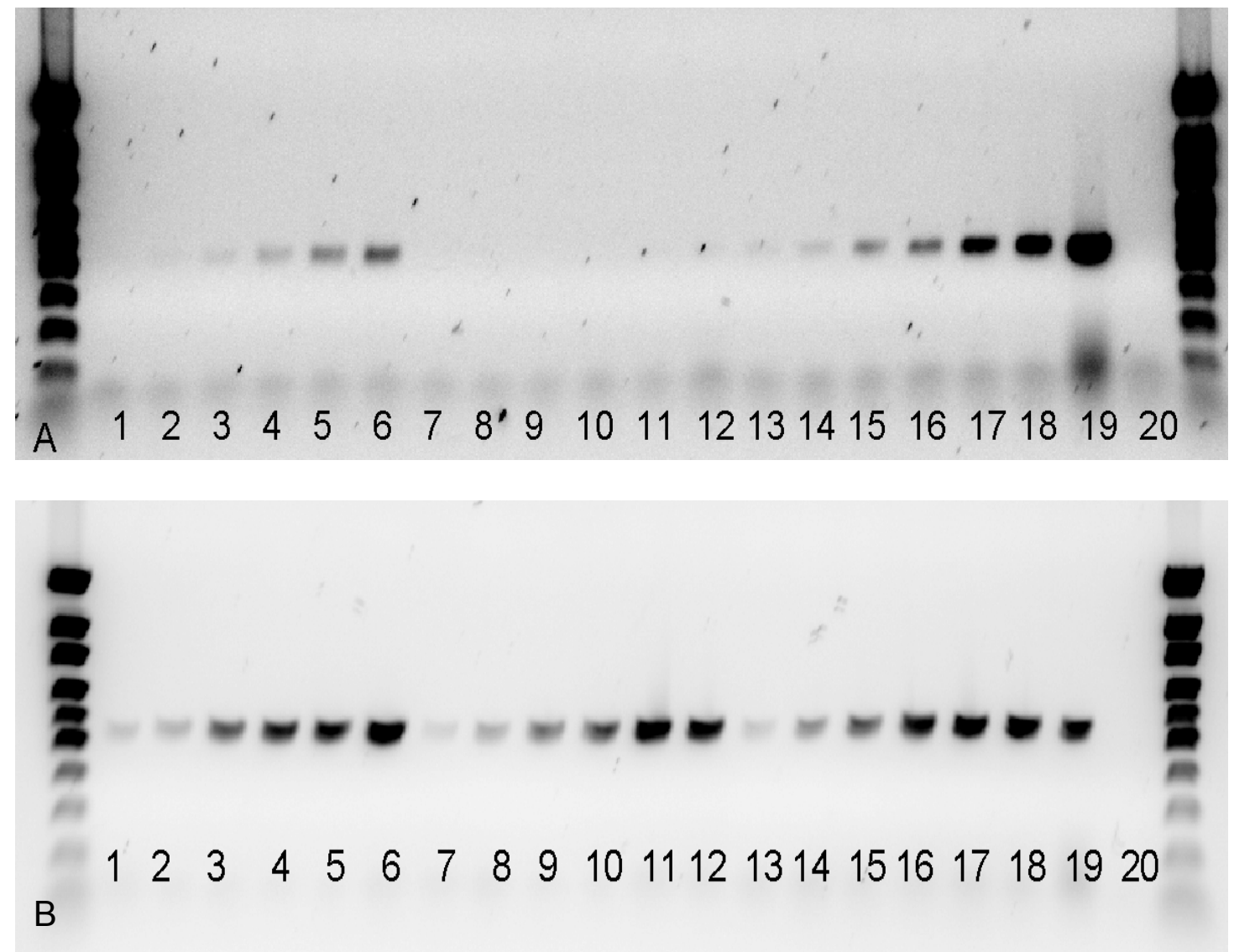

Figure 2 A. Agarose gel of PCR amplicons from DNA samples extracted using Norgen Soil DNA Isolation kit from sieve-concentrated bay water samples spiked with known quantities of Ciona eggs. B. Agarose gel of PCR amplicons from DNA samples extracted using Qiagen DNeasy kit from sieve-concentrated bay water samples spiked with $C$. intestinalis eggs. Ln1=1 egg (undiluted). Ln2=5 eggs (undiluted). Ln3=10 eggs (undiluted). Ln4=20 eggs (undiluted). Ln5=50 eggs (undiluted). Ln6=100 eggs (undiluted). Ln7=1 egg (2-fold dilution). Ln8 $=5$ eggs ( 2 -fold dilution). Ln9=10 eggs (2-fold dilution). Ln10=20 eggs (2-fold dilution). Ln11=50 eggs (2-fold dilution). Ln12=100 eggs (2-fold dilution). Ln13=1 egg (10-fold dilution). Ln14=5 eggs (10-fold dilution). Ln15=10 eggs (10-fold dilution). Ln16=20 eggs (10-fold dilution). Ln17=50 eggs (10-fold dilution). Ln18=100 eggs (10-fold dilution). Ln19= Positive control. Ln20= Negative control. 


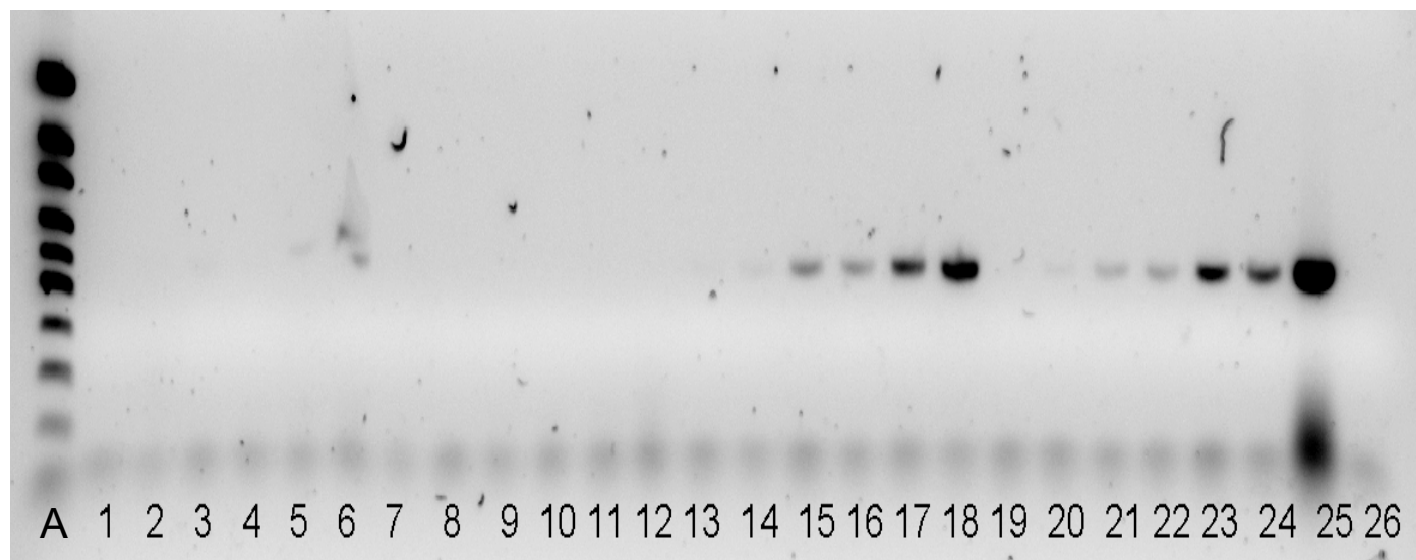

B 1223445562788910111213141516171819202122232425

Figure 3 A. Agarose gel of PCR amplicons from DNA samples extracted using Norgen Soil DNA Isolation kit from direct grab mussel processing effluent water samples spiked with known quantities of Ciona eggs. B. Agarose gel of PCR amplicons from DNA samples extracted using Qiagen DNeasy kit from direct grab mussel processing effluent water samples spiked with $C$. intestinalis eggs. Ln1=1 egg (undiluted). Ln2=5 eggs (undiluted). Ln3=10 eggs (undiluted). Ln4=20 eggs (undiluted). Ln5=50 eggs (undiluted). Ln6=100 eggs (undiluted). $\operatorname{Ln} 7=1$ egg ( $2 \mathrm{X}$ undiluted). Ln8=5 eggs ( $2 \mathrm{X}$ undiluted). Ln9=10 eggs ( $\mathrm{X}$ undiluted). $\operatorname{Ln} 10=20$ eggs ( $2 X$ undiluted). Ln11 $=50$ eggs ( $2 X$ undiluted). Ln12=100 eggs ( $2 X$ undiluted). Ln13=1 egg (2-fold dilution). Ln14=5 eggs (2-fold dilution). Ln15=10 eggs (2-fold dilution). Ln16=20 eggs (2-fold dilution). Ln17=50 eggs (2-fold dilution). Ln18=100 eggs (2-fold dilution). Ln19=1 egg (10-fold dilution). Ln20=5 eggs (10-fold dilution). Ln21=10 eggs (10-fold dilution). Ln22=20 eggs (10-fold dilution). Ln23=50 eggs (10-fold dilution). Ln24=100 eggs (10-fold dilution). Ln25= Positive control. Ln26= Negative control. 


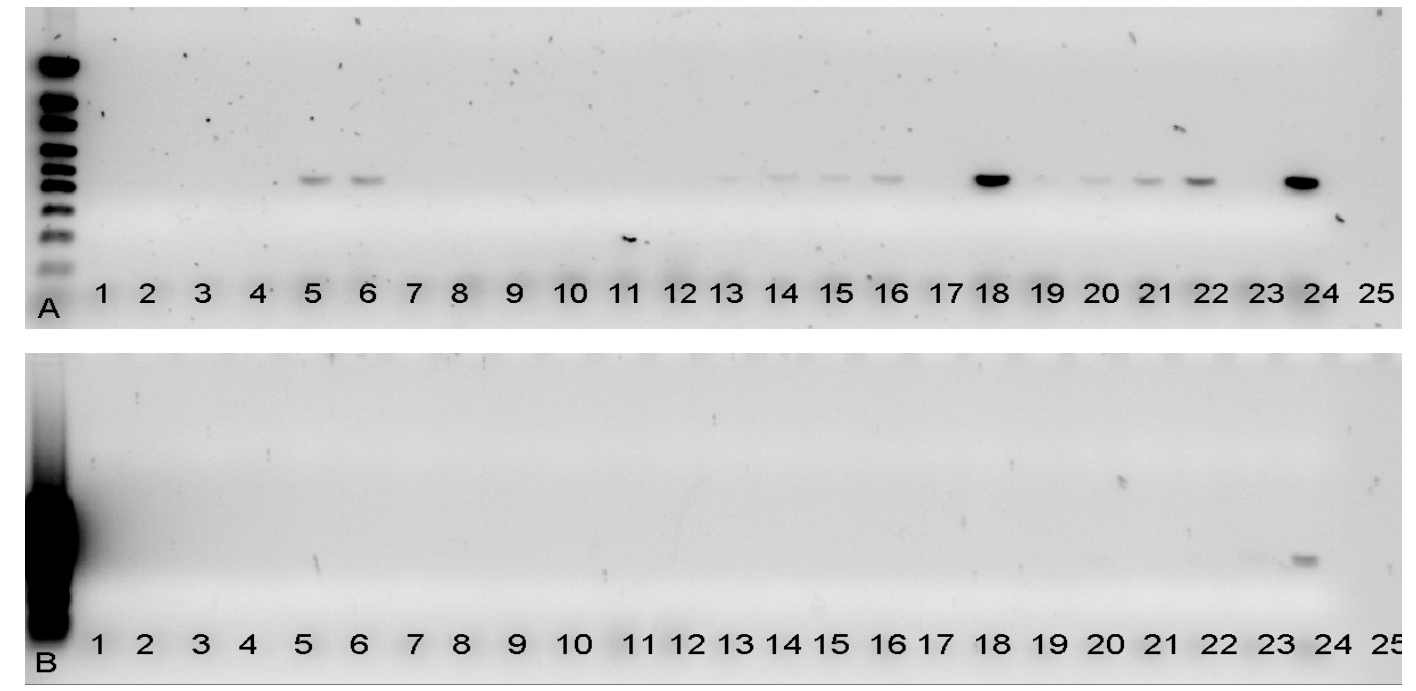

Figure 4 A. Agarose gel of PCR amplicons from DNA samples extracted using Norgen Soil DNA Isolation kit from direct grab mussel processing effluent water samples spiked with known quantities of Ciona eggs. B. Agarose gel of PCR amplicons from DNA samples extracted using Qiagen DNeasy kit from direct grab mussel processing effluent water samples spiked with $C$. intestinalis eggs. Ln1=1 egg (undiluted). Ln2=5 eggs (undiluted). Ln3=10 eggs (undiluted). Ln4=20 eggs (undiluted). Ln5=50 eggs (undiluted). Ln6=100 eggs (undiluted). $\operatorname{Ln} 7=1$ egg ( $2 \mathrm{X}$ undiluted). Ln8=5 eggs $(2 \mathrm{X}$ undiluted). Ln9=10 eggs $(2 \mathrm{X}$ undiluted). $\operatorname{Ln} 10=20$ eggs ( $2 X$ undiluted). Ln11 $=50$ eggs ( $2 X$ undiluted). Ln12=100 eggs ( $2 X$ undiluted). Ln13=1 egg (2-fold dilution). Ln14=5 eggs (2-fold dilution). Ln15=10 eggs (2-fold dilution). Ln16=20 eggs (2-fold dilution). Ln17=50 eggs (2-fold dilution). Ln18=100 eggs (2-fold dilution). Ln19=1 egg (10-fold dilution). Ln20=5 eggs (10-fold dilution). Ln21=10 eggs (10-fold dilution). Ln22=20 eggs ( 10 -fold dilution). Ln23=50 eggs (10-fold dilution). Ln24=100 eggs (10-fold dilution). Ln 25= Negative Control.

\subsection{Sensitivity and Repeatability Study with Spiked Water Samples}

\subsubsection{Ciona Intestinalis Assay}

\subsubsection{Bay Water}

Ciona intestinalis larvae were detected in $100 \%$ of direct grab bay water samples spiked with 1-100 larvae using the CIONAINTESTCOI assay (Figure 5A). C. intestinalis eggs were detected in $94 \%$ of direct grab bay water samples spiked with known quantities of $C$. intestinalis eggs using the CIONAINTESTCOI assay (Figure 5B). The CIONAINTESTCOI assay successfully detected $C$. intestinalis larvae in $94 \%$ of sieve concentrated bay water samples and in $100 \%$ of sieve concentrated water samples spiked with $C$. intestinalis eggs (Figures 5C and 5D). 


\section{Macrothink}

111111155555555101010101010202020202020505050505050100100100100100100 + . A
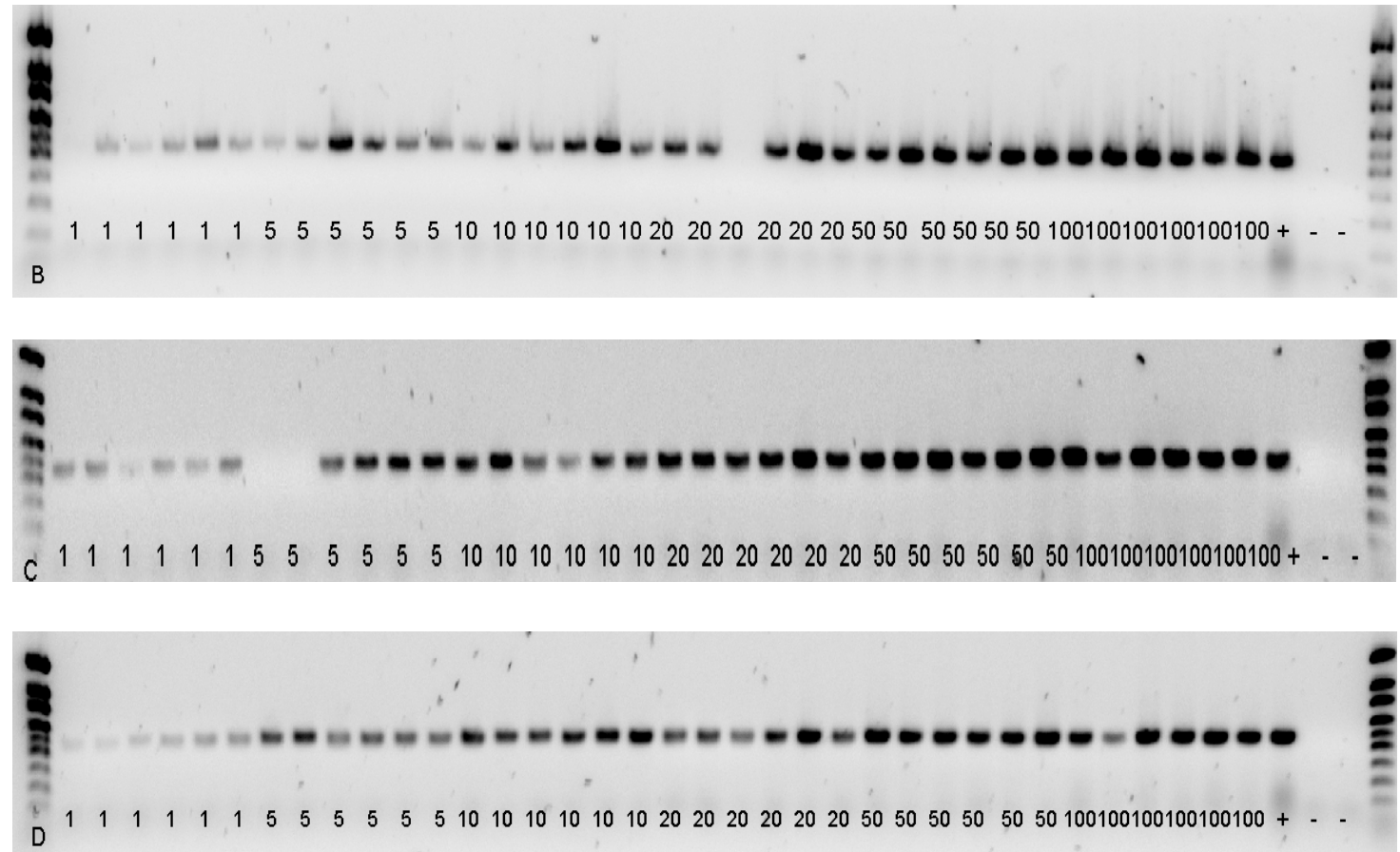

Figure 5. Agarose gels of PCR amplicons with CIONAINTESTCOI assay in bay water samples A. Direct grab bay water spiked with 1, 5, 10, 20, 50 and 100 C. intestinalis larvae B. Sieve-concentrated bay water spiked with 1, 5, 10, 20, 50 and $100 C$. intestinalis larvae. C. Direct grab water spiked with $1,5,10,20,50$ and $100 C$. intestinalis eggs. D. Sieve-concentrated bay water spiked with 1, 5, 10, 20, 50 and 100 C. intestinalis eggs.

\subsubsection{Mussel Processing Plant Effluent Water}

C. intestinalis larvae were detected in $100 \%$ of direct grab mussel processing effluent water samples spiked with 5-100 larvae but in none of the samples spiked with 1 larva (Figure 6A). In sieve-concentrated effluent water samples that were spiked with $C$. intestinalis larvae, the CIONAINTESTCOI assay detected larvae in 100\% of these samples (Figure 6B). The CIONAINTESTCOI assay detected C. intestinalis eggs in 93\% of direct grab effluent water samples spiked with 1-100 quantities of $C$. intestinalis eggs (Figure 6C). This assay also detected $C$. intesitnalis larvae in $100 \%$ of sieve-concentrated effluent water that were spiked with 5-100 larvae but in only 20\% of samples spiked with 1 larva (Figure 6D). 

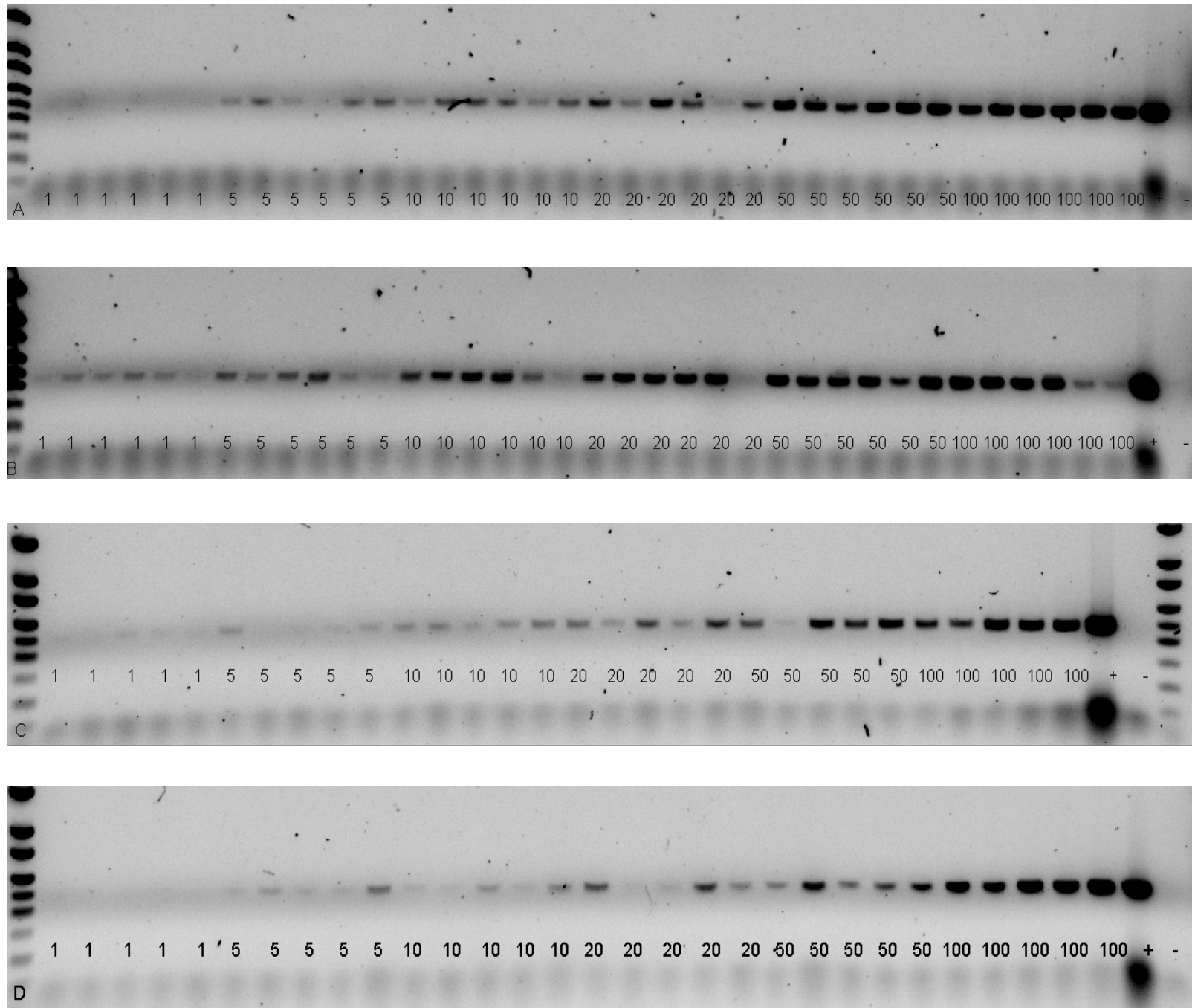

Figure 6. Agarose gels of PCR amplicons with CIONAINTESTCOI assay in mussel processing plant effluent water A. Direct grab mussel processing plant water spiked with 1,5 , 10, 20, 50 and 100 Ciona intestinalis larvae. B. Sieve-concentrated mussel processing plant effluent water spiked with 1, 5, 10, 20, 50 and $100 \mathrm{C}$. intestinalis larvae. C. Direct grab mussel processing effluent water spiked with 1, 5, 10, 20, 50 and 100 C. intestinalis eggs. D. Sieve-concentrated mussel processing effluent water spiked with 1, 5, 10, 20, 50 and $100 C$. intestinalis eggs.

\subsubsection{Styela Clava Assay}

\subsubsection{Bay Water}

In direct grab and sieve-concentrated water samples collected from St. Mary's Bay and spiked with known quantities of $S$. clava larvae, $100 \%$ of all quantities tested (1-100) were detected by the STYCLAV18S assay and $97 \%$ of all quantities of water samples spiked with S. clava eggs were detected with the STYCLAV18S assay (Figure 7A-D). 

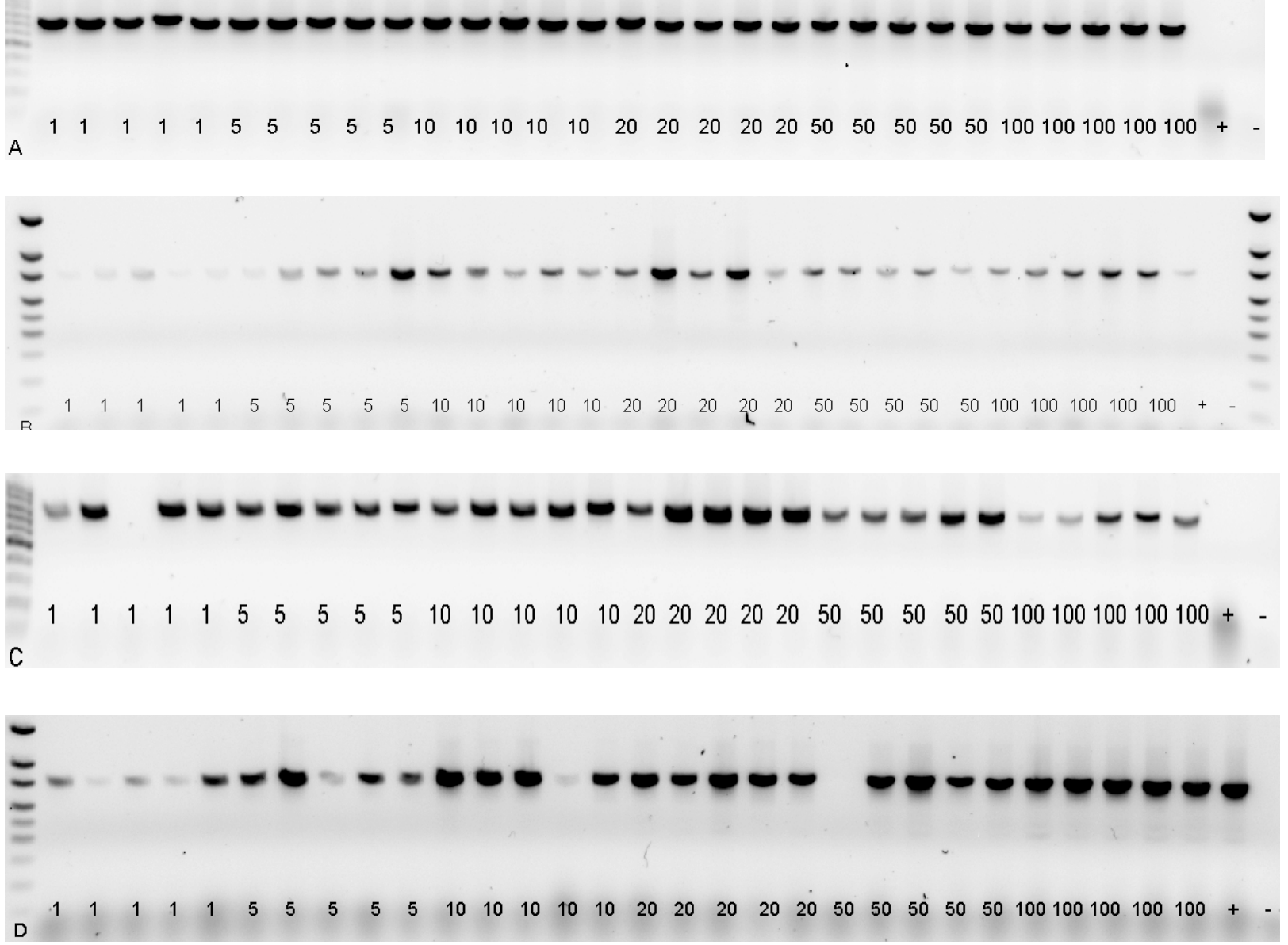

Figure 7. Agarose gels of PCR amplicons from STYCLAV18S assay from bay water samples A. Direct grab bay water samples spiked with 1, 5, 10, 20, 50 and $100 \mathrm{~S}$. clava larvae. B. Sieve-concentrated bay water samples spiked with 1, 5, 10, 20, 50 and $100 \mathrm{~S}$. clava larvae. C. Direct grab water samples spiked with $1,5,10,20,50$ and $100 \mathrm{~S}$. clava eggs. D. Sieve-concentrated water samples spiked with 1, 5, 10, 20, 50 and 100 S. clava eggs.

\subsubsection{Mussel Processing Effluent Water}

In direct grab mussel processing plant effluent water samples spiked with $S$. clava larvae, $100 \%$ of water samples spiked with 5-100 quantities of larvae were detected with the STYCLAV18S assay (Figure 8A). Only $60 \%$ of the water samples spiked with 1 larva were detected with this assay. Sieve-concentrated mussel processing plant effluent water spiked with known quantities of $S$. clava larvae were detected in $100 \%$ of samples that were spiked with 5-100 larvae with the STYCLAV18S assay and in only $40 \%$ of the samples that were spiked with 1 larva (Figure 8B). In direct grab water samples collected from mussel processing plant effluent and spiked with known quantities of $S$. clava eggs, $100 \%$ of all spiked samples were detected with the STYCLAV18S assay (Figure 8C). In sieve concentrated mussel processing plant effluent water that was spiked with $S$. clava eggs, $100 \%$ of samples spiked with all quantities of eggs were detected with the STYCLAV18S assay (Figure 8D). 

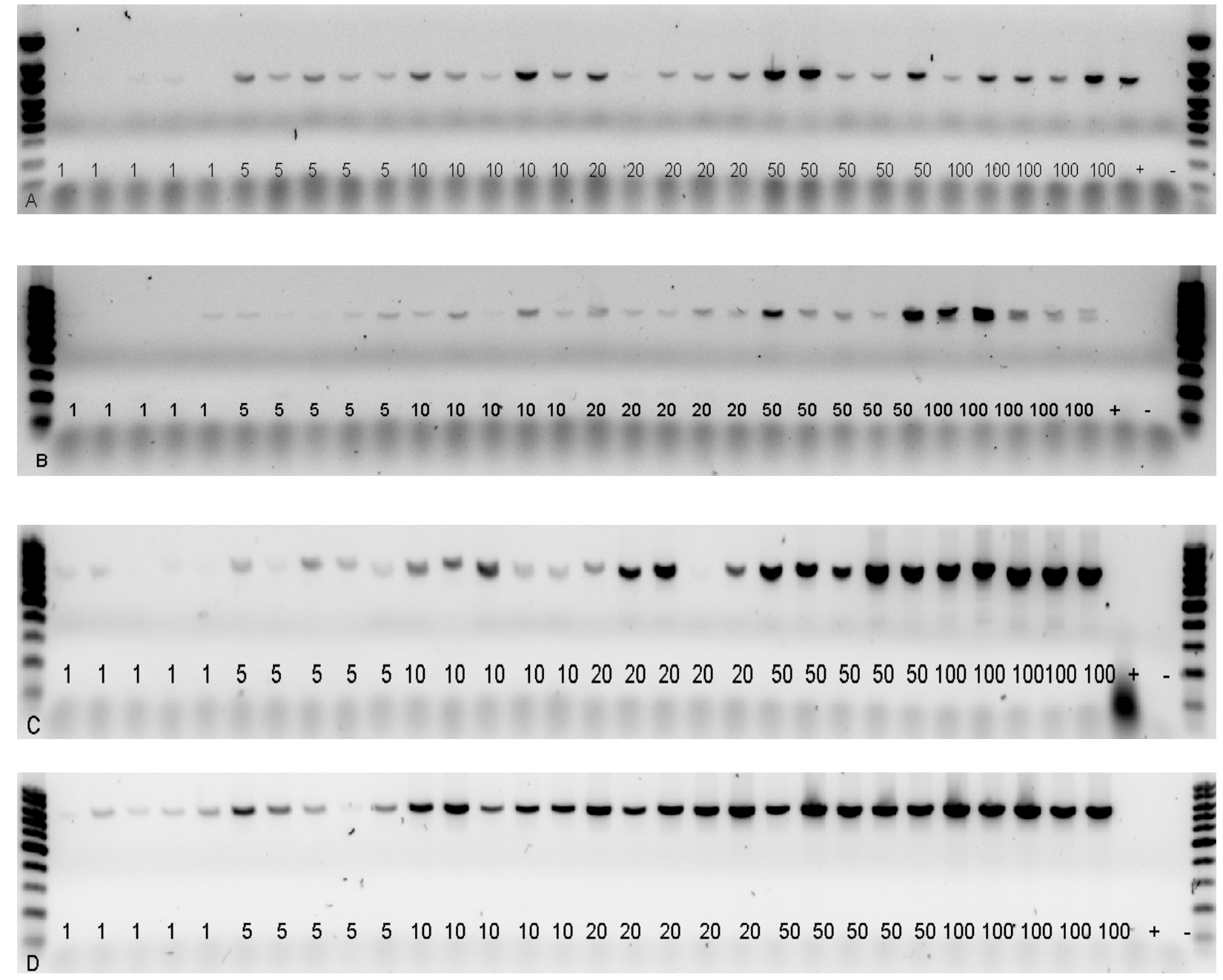

Figure 8. Agarose gels of PCR amplicons from STYCLAV18S assay from mussel processing plant effluent water samples A. Direct grab mussel processing plant effluent water samples spiked with $1,5,10,20,50$ and $100 \mathrm{~S}$. clava larvae. B. Sieve-concentrated musself processing plant effluent water samples spiked with 1, 5, 10, 20, 50 and $100 \mathrm{~S}$. clava larvae. C. Direct grab mussel processing plant effluent water samples spiked with 1, 5, 10, 20, 50 and 100 S. clava eggs. D. Sieve-concentrated mussel processing plant effluent water samples spiked with 1, 5, 10, 20, 50 and 100 S. clava eggs.

\subsubsection{Botryllus Schlosseri Assay}

\subsubsection{Bay Water}

The BOTSCHLOCOI assay detected B. schlosseri in $90 \%$ of all zooid and colony spiked direct grab bay water samples (Figure 9A)

\subsubsection{Mussel Processing Plant Effluent Water}

The BOTSCHLOCOI assay detected B. schlosseri colonies and zooids in $100 \%$ of samples tested from both the direct grab spiked water samples and the sieve-concentrated water samples (Figure 9B \& C). 

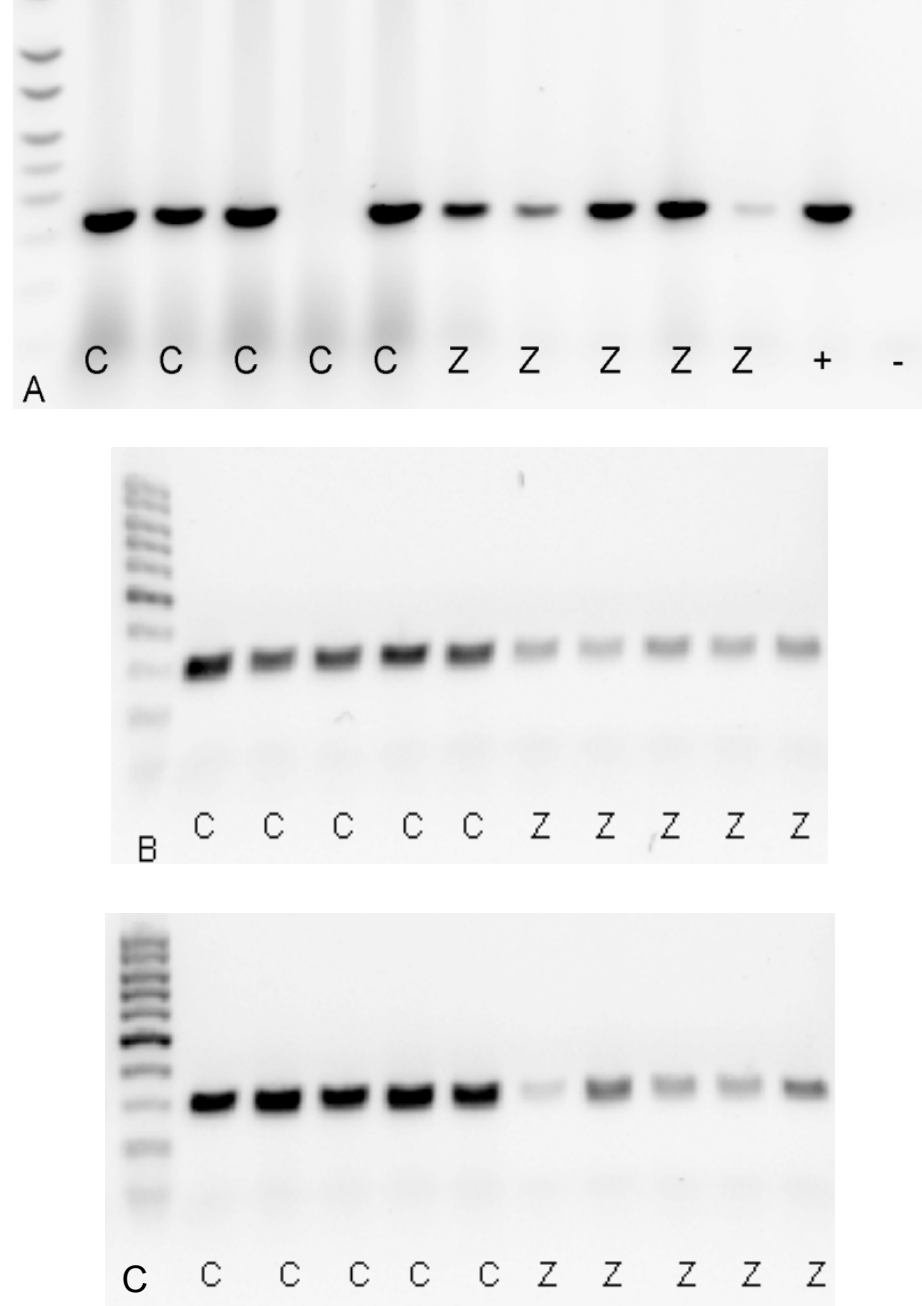

Figure 9. Agarose gels of PCR amplicons from BOTSCHLOCOI assay spiked with colony (C) or zooid (Z) from Botryllus schlosseri. A. Sieve-concentrated bay water. B. Sieve-concentrated mussel processing plant effluent water. C. Direct grab mussel processing plant effluent water.

\subsubsection{Botrylloides Violaceus Assay}

\subsubsection{Bay Water}

Botrylloides violaceus was detected in $100 \%$ of the direct grab bay water samples that were spiked with zooid and colony quantities of B. violaceus using the BOTVIOLET18S assay (Figure 10A).

\subsubsection{Mussel Processing Plant Effluent Water}

The BOTVIOLET18S assay detected B. violaceus in $100 \%$ of all direct grab and sieve-concentrated mussel processing effluent water spiked with zooid and colonies of $B$. violaceus (Figure 10B \&C). 

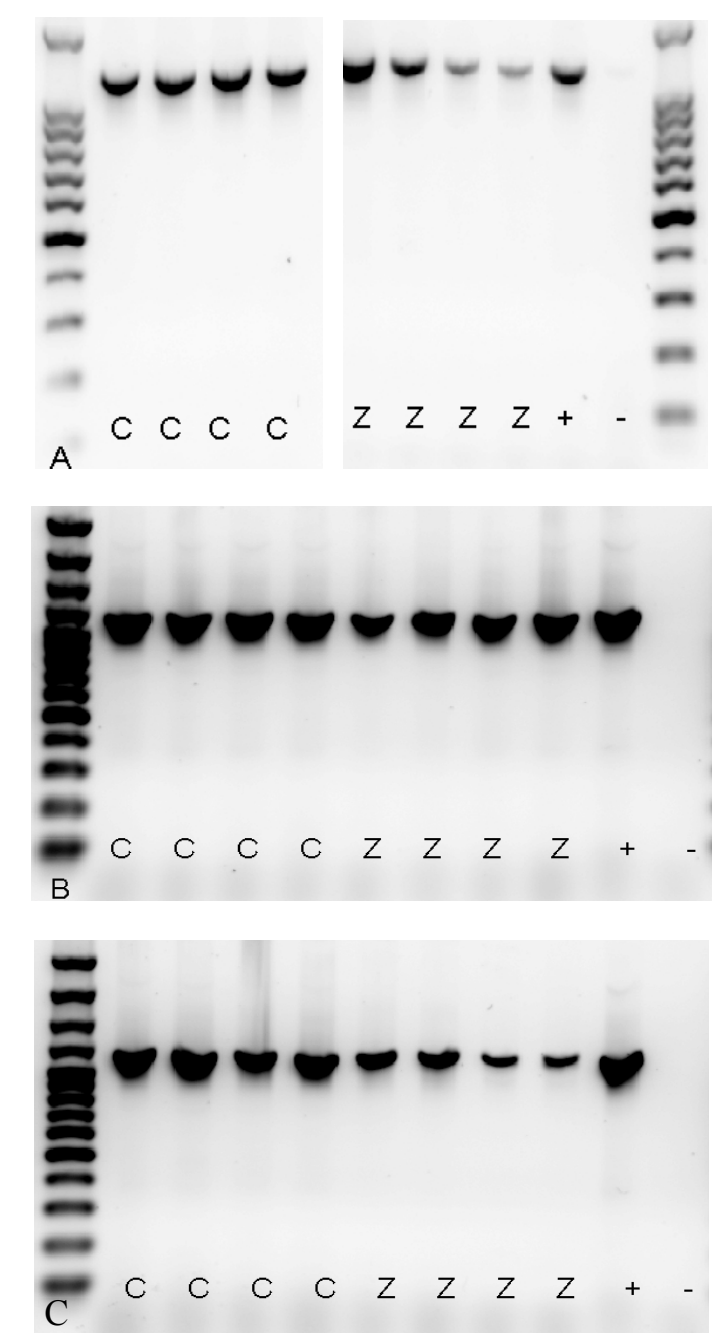

Figure 10. Agarose gels of PCR amplicons from BOTVIOLET18S assays from water samples spiked with colony (C) and zooid (Z) of Botrylloides violaceus A. Sieve-concentrated bay water samples. B. Sieve-concentrated mussel processing plant effluent water samples. C. Direct grab mussel processing plant effluent water samples.

\subsection{Comparison with Industry Standard}

Using the industry standard microscope analysis, S. clava larvae were detected in water samples from Darnley Basin, Murray River and Marchwater while C. intestinalis larvae were detected in water samples from Cardigan River, Montague River, Boughton River, St. Mary's Bay and Murray River. No eggs or larvae from B. violaceus or B. schlosseri were detected in any of the water samples in this study.

Using molecular assays, $S$. clava was detected in water samples from Darnley Basin and Marchwater while $C$. intestinalis was detected in water samples from Cardigan River, Montague River, Boughton River, and St. Mary's Bay (Figure 11A \&B). No material from $B$. violaceus or B. schlosseri was detected in water samples by the molecular assays (Figure 12A $\& B)$. 

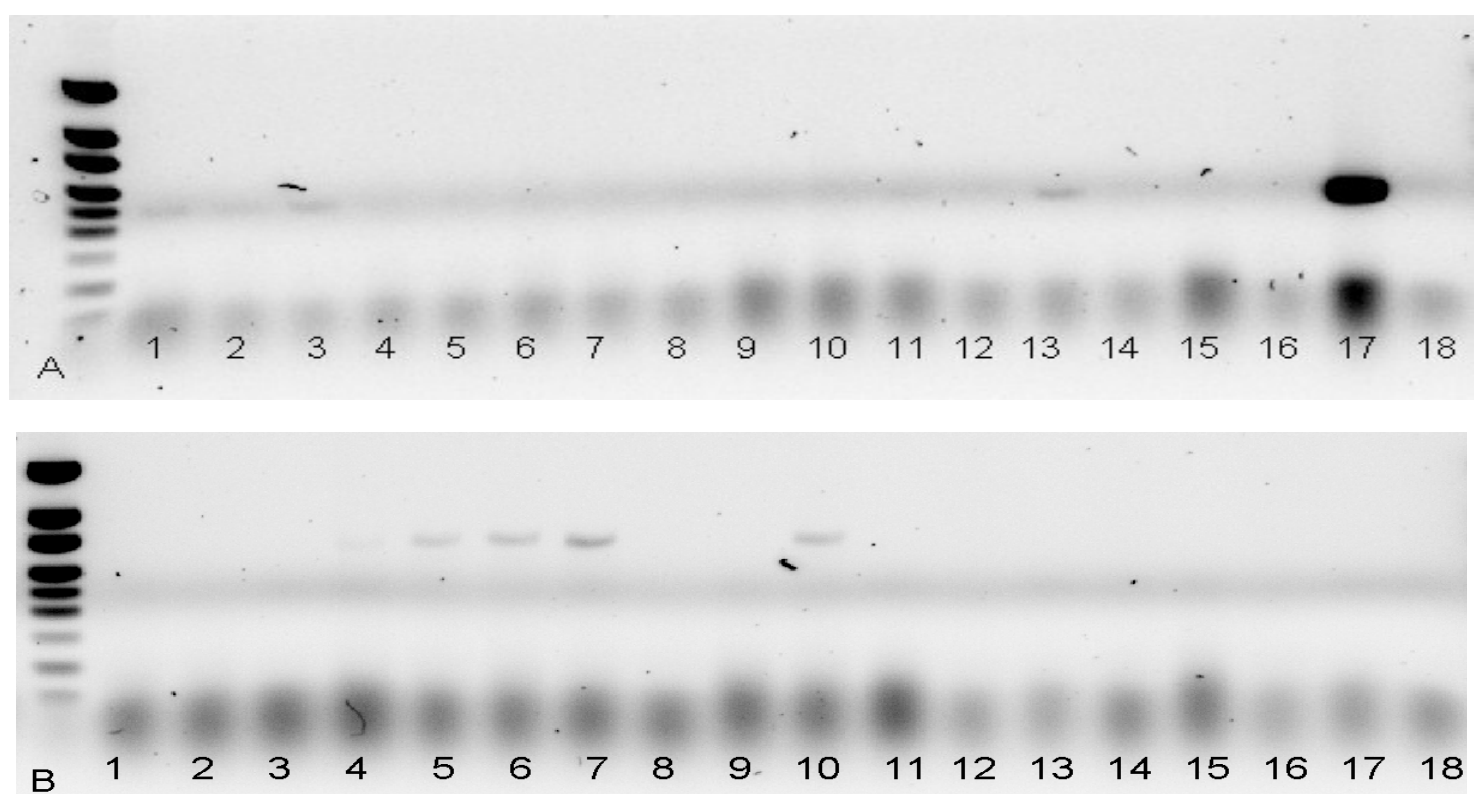

Figure $11 \mathrm{~A}$. Agarose gel of PCR amplicons from the CIONAINTESTCOI assay with water samples from PEI. B. Agarose gel of PCR amplicons from the STYCLAV18S assay with water samples from PEI. Ln1=Montague River. Ln2= St. Mary's Bay. Ln3= Boughton River. Ln4= Darnley Basin. Ln5=Marchwater. Ln6=Marchwater. Ln7=Marchwater. Ln8=Murray River. Ln9 $=$ Cardigan River. Ln10=Darnley Basin. Ln11=Cardigan River. Ln12= Murray River. Ln13=Boughton River. Ln14=Marchwater. Ln15=Cardigan River. Ln16=Murray River. Ln17=Positive Control. Ln18= Negative Control.

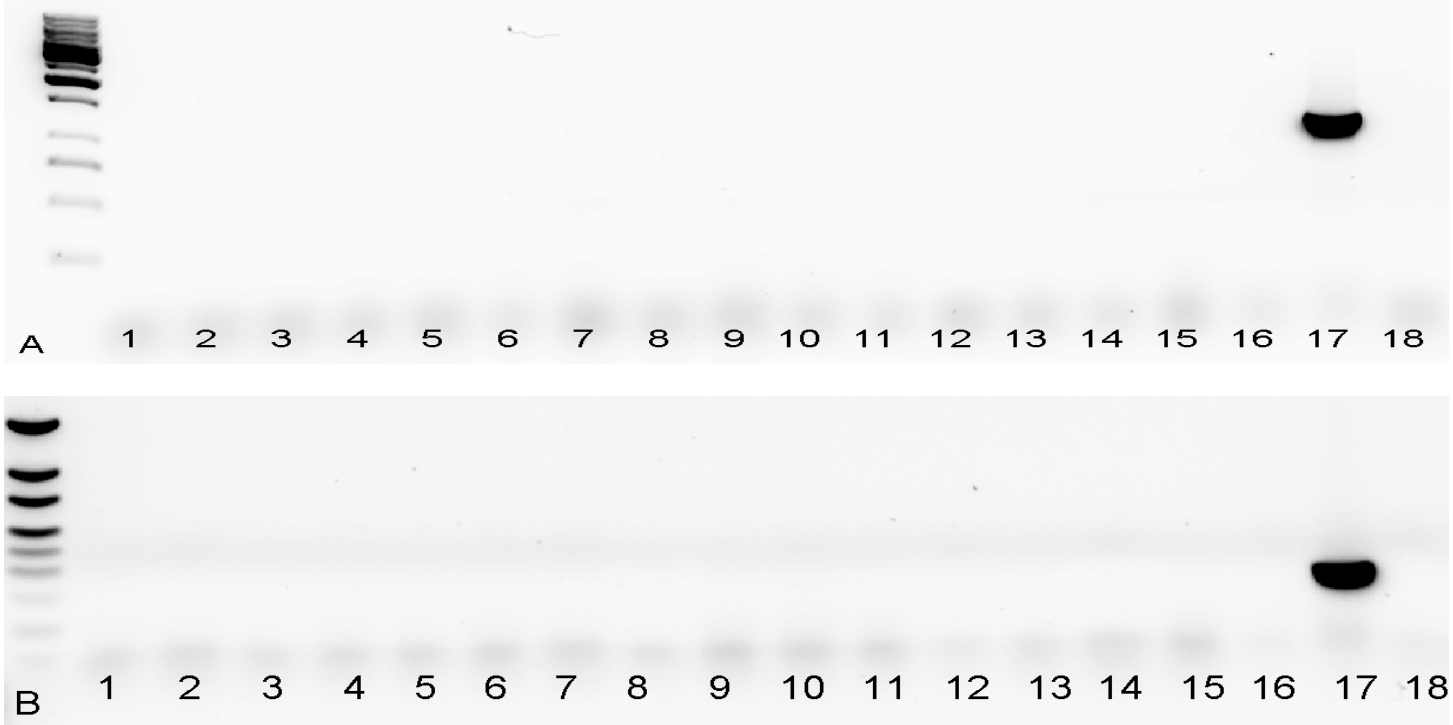

Figure 12 A. Agarose gel of PCR amplicons from the BOTVIOLET18S primer sets with water samples from PEI. B. Agarose gel of PCR amplicons from the BOTSCHLOCOI primer sets with samples from PEI. Ln1=Montague River. Ln2= St. Mary's Bay. Ln3= Boughton River. Ln4= Darnley Basin. Ln5=Marchwater. Ln6=Marchwater. Ln7=Marchwater. Ln8=Murray River. Ln9=Cardigan River. Ln10=Darnley Basin. Ln11=Cardigan River. Ln12= Murray River. Ln13=Boughton River. Ln14=Marchwater. Ln15=Cardigan River. Ln16=Murray River. Ln17=Positive Control. Ln18= Negative Control. 


\section{Discussion}

\subsection{Optimization of Assay Protocols}

\subsubsection{DNA Extraction Kits}

The Qiagen DNeasy DNA extraction kit was successful in extracting amplifiable DNA from both direct grab and sieve-concentrated bay water samples. However, this kit was not able to extract amplifiable DNA from the mussel processing effluent water, which contains more sediment and accompanying PCR inhibitors than the bay water used in this study. Qiagen QIAamp DNA extraction kits were also unable to remove inhibitors in other studies in which more specialized soil extraction kits were successful in removing inhibitors from DNA samples (Alexandrino et al., 2004; Behets et al., 2007). While the Qiagen kits do remove some inhibitors during the extraction method, they are not specialized extraction methods developed for use with environmental samples which are high in inhibitory compounds. The Norgen Soil DNA Isolation kit has targeted steps during the extraction procedure which use both chemical and physical methods to separate inhibitors such as humic acids from the nucleic acid sample. These steps were sufficient to remove the PCR inhibitors in the mussel effluent processing water in our study. However, the Norgen Soil DNA Isolation kit did not extract amplifiable DNA from bay water samples that were low in sediment content. Spectrophotometer analysis showed that DNA was extracted from these samples; however this DNA appeared sheared when run through an agarose gel (data not shown). The Norgen extraction method includes a step in which samples are vortexed with bead tubes and it appears that in the absence of heavy sediment loads, DNA is sheared during this process. As a result, we recommend using Qiagen DNeasy kits to extract DNA from water samples low in sediment (such as bay water) and Norgen Soil DNA Isolation kits to extract DNA in water samples that are high in sediment (such as mussel processing plant effluent or bay water which is sediment rich). These results are similar to Behets et al. (2007), who also determined that Qiagen DNA extraction kits were sufficient in one water sample type but that a second type of water had enough inhibitors to require a specialized soil DNA isolation kit to overcome the inhibition in a diagnostic assay for Legionella pneumophila.

\subsubsection{Sample Dilution in PCR}

From the dilution study, it is clear that in high sediment mussel processing plant effluent water samples, diluting the DNA samples 10 -fold prior to adding them to PCR is optimal for assay sensitivity. This indicates that while the Norgen Soil DNA Isolation kit is successful in removing most of the PCR inhibitors from the DNA samples, enough inhibitors remain to have an inhibitory effect on the assay. By diluting the samples with distilled water, the concentration of inhibitors is decreased below the inhibition threshold, allowing amplification to occur despite the fact that the DNA concentration is also diluted in the process. Using dilutions to overcome this inhibition threshold has also been exhibited in other studies (Verkooyen et al., 1996; Kemp et al., 2006). Sample dilution had no significant impact on the Qiagen extracted bay water samples, since these samples did not contain high levels of inhibitory compounds in the initial water samples. 


\subsubsection{Water Sampling Method}

Assay sensitivity did not appear to be impacted by water sample collection method, since assay performance was similar in both direct grab and sieve concentrated spiked samples. Since there would be a greater chance of detecting tunicate eggs or larvae in the sieve-concentrated method (since a higher volume of water is sampled) we would recommend using the sieve-concentrated method of sampling with these assays. This is particularly important in bay water sampling since the concentration of tunicate eggs and larvae is lower than in mussel processing effluent water (Bourque et al., 2006; PEI Department of Fisheries, Aquaculture and Rural Development 2009).

\subsection{Sensitivity Analysis with Spiked Field Water Samples}

In both bay water and mussel processing effluent water, the four species specific assays were very sensitive in detecting eggs, larvae, zooids and colonies of invasive tunicates in this study. The CIONAINTESTCOI assay detected $97 \%$ of all quantities of egg and larvae tested in bay water samples to a sensitivity of 1 egg or larva. This assay also detected $100 \%$ of $C$. intestinalis eggs and larvae tested in mussel processing effluent to a sensitivity of 5 larvae or eggs. The STYCLAV18S assay detected $98 \%$ of all quantities of S. clava eggs and larvae in bay water samples to a sensitivity of 1 egg and 1 larva. This assay also detected $100 \%$ of $S$. clava eggs and larvae in mussel processing plant effluent sample to a sensitivity of 5 larvae. The BOTSCHLOCOI assay detected B. schlosseri in $90 \%$ of bay water samples and $100 \%$ of mussel processing plant effluent to a sensitivity of 1 zooid. The BOTVIOLET18S assay detected B. violaceus in $100 \%$ of bay water and mussel processing plant effluent water to a sensitivity of 1 zooid. The high sensitivity in these four assays is comparable to other assays developed to detect larvae of invasive species such as 1-5 larvae in Limnoperna fortunei, (Boeger et al. 2007), 1 cyst in Gymnodinium catenatum (Patil et al., 2005) and 1 zoea in Carcinus sp. (Darling \& Tepolt, 2008).

\subsection{Comparison with Industry Standard}

Both microscopy and molecular analysis are in congruence with the negative results for both colonial species of tunicate (B. schlosseri and B. violaceus) in each river and bay tested for invasive tunicates in this study. These negative values are not surprising as the colonial tunicates are not frequently found in large numbers in these regions. In fact, during the weekly May-November testing of these rivers and bays by the PEI Department of Fisheries, Aquaculture and Rural Development, only one bay (St. Mary's) tested positive for colonial tunicate larvae on one collection date. The STYCLAV assay detected $S$. clava in $2 / 3$ of the positive microscope samples. The CIONAINTESTCOI assay detected $C$. intestinalis in $4 / 5$ of the positive microscope samples. The decreased sensitivity between the two methods is likely due to the fact that the microscope analysis occurred first while samples were fresh. Following analysis with the microscope, samples were stored for up to two days at $-4^{\circ} \mathrm{C}$ in tap water prior to molecular analysis. Exposure to tap water and freezing at $-4^{\circ} \mathrm{C}$ may have led to nucleic acid degradation. In addition the 1-2 larvae detected during the microscope analysis may not have all been recovered from the counting wheel when samples were washed back into sample tubes for molecular analysis. In the samples collected in this study 
from bay water, the molecular assays were able to positively detect 3 larva in 150 litres of water.

\section{Conclusion}

Invasive species management requires surveillance and monitoring programs that have the capacity to detect invasive species in new regions before population levels become too large to control (Mehta et al., 2007). Increasingly, PCR is being used to detect aquatic invasive species eggs and larvae in surface and ballast water samples (Patil et al., 2005; Boeger et al., 2007; Darling \& Tepolt, 2008) since large quantities of water can be screened for trace amounts of eggs and larvae in a high throughput manner. PCR assays are also powerful diagnostic techniques because the technology and equipment are now available in any molecular biology laboratory making developed assays accessible to many regions. As the results of this study show, PCR assays can perform differently in different water sample types, and it is critical that molecular assays be validated in each specific situation in which they are used. Characteristics of the water samples, such as the presence of PCR inhibitory compounds and the presence of non-target organisms can impact assay sensitivity. As this study shows, inhibition can be overcome by troubleshooting extraction methods and PCR protocols. Since molecular assay performance is also dependent on the specificity of the primer sequence, haplotypes in different geographic regions may also impact assay efficacy. For this reason, assays should also be validated when used in new geographic regions.

This study has demonstrated the powerful sensitivity of the four species specific invasive tunicate assays to detect 1-5 eggs and larvae in both bay water and mussel processing plant effluent water in Prince Edward Island. Both the sensitivity and repeatability of the four assays make them excellent candidates for invasive species monitoring programs. The high throughput nature of these assays makes them excellent monitoring tools for invasive species monitoring. Up to 96 molecular assays can be performed per day, whereas microscopic analysis currently takes 30 minutes per water sample. It is hoped that these assays can be integrated into monitoring programs for invasive tunicates in Prince Edward Island since early detection is critical in invasive species control and management.

\section{Acknowledgements}

Funding for this study came from the Canadian Aquatic Invasive Species Network (CAISN). The authors wish to thank the AVC Shellfish Research Group for water and tunicate sample collections and the AVC Lobster Science Centre for access to their laboratory equipment and facility. Specific thanks to Sarah Haimes for collecting water at the mussel processing plant and to Prince Edward Aquafarms for access to their effluent water treatment facility. The authors also wish to thank Fraser Clark, Daniel Bourque and Thomas Landry for technical advice. The authors would also like to acknowledge the contribution of Aaron Ramsay and the Prince Edward Island Department of Fisheries, Aquaculture and Rural Development for the water collection and microscope analysis of water samples collected in the industry comparison aspect of this study. The authors would also like to thank the two anonymous reviewers whose comments strengthened this manuscript. 


\section{References}

Alexandrino, M., Grohmann, E., \& Szewzyk, U. (2004). Optimization of PCR-based methods for rapid detection of Campylobacter jejuni, Campylobacter coli and Yersinia enterocolitica serovar 0:3 in wastewater samples. Water Research, 38, 1340-1346. http://dx.doi.org/10.1016/j.watres.2003.10.036

Altshuler, A. (2006). PCR Troubleshooting: The Essential Guide. Norfolk: Caister Academic Press.

Behets, J., Declerck, P., Delaedt, Y., Creemers, B., \& Ollevier, F. (2007). Development and evaluation of a Taqman duplex real-time PCR quantification method for reliable enumeration of Legionella pneumophila in water samples. Journal of Microbiological Methods, 68, 137-144. http://dx.doi.org/10.1016/j.mimet.2006.07.002

Boeger, W. A., Rie, M. R., Falleiros, R. M., Ostrensky, A., Darrigran, G., Mansur, M. C. D., \& Belz, C. E. (2007). Testing a molecular protocol to monitor the presence of golden mussel larvae (Limnoperna fortunei) in plankton samples. Journal of Plankton Research, 29, 1015-1019. http://dx.doi.org/10.1093/plankt/fbm075

Bourque, D. (2006). Evaluating and managing the role of processing plants as vectors for aquatic invasive species. Oral Presentation at Aquaculture Canada ${ }^{\mathrm{OM}}$ November 19-22. Halifax, NS, Canada.

Cunningham, C. O. (2002). Molecular diagnosis of fish and shellfish diseases: present status and potential use in disease control. Aquaculture, 206, 19-55. http://dx.doi.org/10.1016/S0044-8486(01)00864-X

Darling, J. A., \& Tepolt, C. K. (2008). Highly sensitive detection of invasive shore crab (Carcinus maenas and Carcinus aestuarii) larvae in mixed plankton samples using polymerase chain reaction and restriction fragment length polymorphisms (PCR-RFLP). Aquatic Invasions, 3, 141-152. http://dx.doi.org/10.3391/ai.2008.3.2.4

Gill, K., MacNair, M., \& Morrison, A. (2007). Investigation into the life cycle, impact on mussel culture and mitigation strategies for the vase tunicate (Ciona intestinalis), a new invasive species in the Montague/Brudenell River systems. PEI Department of Fisheries and Aquaculture Project \# 062AR20.

Hoorfar, J., Wolffs, P., \& Rådström, P. (2004). Diagnostic PCR: validation and sample preparation are two sides of the same coin. APMS, 112, 808-814. http://dx.doi.org/10.1111/j.1600-0463.2004.apm11211-1207.x

Jacobson, R. H. (1996). Principles of validation of diagnostic assays for infectious diseases. Manuals of Standards for Diagnostic Tests and Vaccines. OIE. France.

Johnson, D. W., Pieniazek, N. J., Griffin, D. W., Misener, L., \& Rose, J. B. (1995). Development of a PCR protocol for sensitive detection of Cryptosporidium oocysts in water samples. Applied and Environmental Microbiology, 61, 3849-3855. 
Kemp, B. M., Monroe, C., \& Smith, D. G. (2006). Repeat silica extraction: a simple technique for the removal of PCR inhibitors from DNA extracts. Journal of Archaeological Science, 33, 1680-1689. http://dx.doi.org/10.1016/j.jas.2006.02.015

Kourenti, C., \& Karanis, P. (2006). Evaluation and applicability of a purification method coupled with nested PCR for the detection of Toxoplasma oocysts in water. Letters in Applied Microbiology, 43, 475-481. http://dx.doi.org/10.1111/j.1472-765X.2006.02008.x

Mehta, S. V., Haight, R. G., Homans, F. R., Polasky, S., \& Venette, R. C. (2007). Optimal detection and control strategies for invasive species management. Ecological Economics, 61, 237-245. http://dx.doi.org/10.1016/j.ecolecon.2006.10.024

Patil, J. G., Gunasekera, R. M., Deagle, B. E., Bax, N. J., \& Blackburn, S. I. (2005). Development and evaluation of a PCR based assay for detection of the toxic dinoflagellate, Gymnodinium catenatum (Graham) in ballast water and environmental samples. Biological Invasions, 7, 983-994. http://dx.doi.org/10.1007/s10530-004-3119-8

PEI Department of Fisheries, Aquaculture and Rural Development. (2009). Mussel Monitoring Results. http://www.gov.pe.ca/fard/fisheries/index.php3

Ramsay, A. P., Davidson, J., Landry, T., \& Arsenault, G. (2008). Process of invasiveness among exotic tunicates in Prince Edward Island, Canada. Biological Invasions, 10, 1311-1316. http://dx.doi.org/10.1007/s10530-007-9205-y

Stewart-Clark, S. E., Siah, A., Greenwood, S. J., Davidson, J., \& Berthe, F. C. J. (2009). Development of $18 \mathrm{~S}$ rDNA and COI gene primers for the identification of invasive tunicate species in water samples. Aquatic Invasions, 4, 575-580. http://dx.doi.org/10.3391/ai.2009.4.4.2

Tebbe, C. C., \& Vahjen, W. (1993). Interference of humic acids and DNA extracted directly from soil in detection and transformation of recombinant DNA from bacteria and a yeast. Applied and Environmental Microbiology, 59, 1657-2665.

Thompson, R., \& MacNair, N. (2004). An overview of the clubbed tunicate (Styela clava) in Prince Edward Island. Fisheries and Aquaculture Technical Report \# 234. PEI Department of Agriculture, Fisheries, Aquaculture and Forestry.

Toze, S. (1999). PCR and the detection of microbial pathogens in water and wastewater. Water Research, 33, 3545-3556. http://dx.doi.org/10.1016/S0043-1354(99)00071-8

Verkooyen, R. P., Luijendijk, A., Huisman, W. M., Goessens, W. H. F., Kluytmans, J. A. J. W., Van Rijsoort-Vos, J. H., \& Verbrugh, H. A. (1996). Detection of PCR inhibitors in cervical specimens by using the AMPLICOR Chlamydia trachomatis assay. Journal of Clinical Microbiology, 34, 3072-3074.

Whitehouse, C. A., \& Hottel, H. E. (2007). Comparison of five commercial DNA extraction kits for the recovery of Francisella tularensis DNA from spiked soil samples. Molecular and Cellular Probes, 21, 92-96. http://dx.doi.org/10.1016/j.mcp.2006.08.003 
Wilson, I. G. (1997). Inhibition and facilitation of nucleic acid amplification: Minireview. Applied and Environmental Microbiology, 63, 3741-3751.

Xiao, L., Singh, A., Limor, J., Graczyk, T. K., Gradus, S., \& Lal, A. (2001). Molecular characterization of Cryptosporidium oocysts in samples of raw surface water and wastewater. Applied and Environmental Microbiology, 67, 1097-1101. http://dx.doi.org/10.1128/AEM.67.3.1097-1101.2001

\section{Copyright Disclaimer}

Copyright reserved by the author(s).

This article is an open-access article distributed under the terms and conditions of the Creative Commons Attribution license (http://creativecommons.org/licenses/by/3.0/). 